\title{
Developing Service User Skills in Co-Production of Research: Course Development and Evaluation
}

McGlade, A., Taylor, B., Killick, C., Lyttle, E., Patton, S., \& Templeton, F. (2020). Developing Service User Skills in Co-Production of Research: Course Development and Evaluation. Journal of Evidence-Based Social Work, 17(4), 486-502. https://doi.org/10.1080/26408066.2020.1766622

Link to publication record in Ulster University Research Portal

\section{Published in:}

Journal of Evidence-Based Social Work

Publication Status:

Published online: $23 / 06 / 2020$

DOI:

10.1080/26408066.2020.1766622

\section{Document Version}

Author Accepted version

\section{General rights}

Copyright for the publications made accessible via Ulster University's Research Portal is retained by the author(s) and / or other copyright owners and it is a condition of accessing these publications that users recognise and abide by the legal requirements associated with these rights.

\section{Take down policy}

The Research Portal is Ulster University's institutional repository that provides access to Ulster's research outputs. Every effort has been made to ensure that content in the Research Portal does not infringe any person's rights, or applicable UK laws. If you discover content in the Research Portal that you believe breaches copyright or violates any law, please contact pure-support@ulster.ac.uk. 


\title{
Developing service user skills in coproduction of research: course development and evaluation
}

Anne McGlade

Social Care Research Lead, Health and Social Care Board for Northern Ireland

Brian J Taylor

Professor of Social Work, Ulster University, Northern Ireland

Campbell Killick

Lecturer in Social Work, Ulster University, Northern Ireland

Elizabeth Lyttle

Service User

Sonia Patton

Service User and Patient Advocate

Fiona Templeton

Service User

CORRESPONDING AUTHOR: Anne McGlade, Social Care Research Lead, Health and Social Care Board for Northern Ireland. anne.mcglade@hscni.net

CITE AS: McGlade A, Taylor BJ, Killick C, Lyttle E, Patton S \& Templeton F (2020) Developing service user skills in co-production of research: course development and evaluation. Journal of Evidence-Based Social Work, 17(4), 486-502. https//:doi.10.1080/26408066.2020.1766622 [accepted 02 May 2020; version of record online 23 June 2020; published 21 July 2020]

\begin{abstract}
The purpose of this article is to enhance understanding of the increasing importance of service user and carer involvement in social work research. The paper outlines actions taken to develop knowledge and skills at post qualifying level. In 2016 three postgraduate modules on research methods and evidence-into-practice for service users and carers were created and taught jointly with existing parallel post-qualifying modules for experienced social workers. Over a three-year period 2016-2019 modular assessments; pre and post testing of knowledge and self-efficacy; regular participant feedback sheets; and end-of-course reflections were undertaken. Qualitative feedback indicated that the classroom experience was regarded positively. Valuable literature reviews and projects were produced which have the potential to contribute to transferring knowledge into practice. Though small in scale and using nonvalidated tools, increased mean scores were recorded on both Test of Knowledge (3.97; $\mathrm{p}<.001)$ and Self Efficacy $(478.8(\mathrm{p}<.001)$ showing promise. Formal measures, exam results and informal feedback demonstrate the success of the initiative as a means of enhancing wider understanding of user participation in the research process. Demonstrating how well equipped service users and carers are to be more effective on research advisory panels and grant committees will take more time. Providing teaching on research methods for service users jointly with experienced social workers shows potential for developing coproduction of social care research and translating evidence into practice.
\end{abstract}

\section{Keywords}

Coproduction; service user; carer; research; education.

User and carer involvement is increasingly a key driver for cultural change within social work. In supporting better outcomes for service users and carers, social care (including social 
work) research seeks to build a culture of evidence and knowledge to inform practice at policy, management and practice levels (Moriarty et al., 2007). INVOLVE, part of the National Institute for Health Research (NIHR), is widely recognized as a leading voice which promotes public participation in all stages of the research process in health, public health and social care.

With acceptance at policy level there is now a need to train a pool of people with the required skills and knowledge to confidently and competently engage in research and 'evidence-into-practice' activity (Lockey et al., 2004). The position since that time in terms of available training has been often targeted at a specific group or a specific project.

It was against this backdrop that a decision was taken in Northern Ireland to advance the position of service user involvement in social work research through the development of relevant knowledge and skills. Work commenced in 2016 on the development over a three year period of three postgraduate modules for social services users and carers on research and review methods, and skills in transferring knowledge to practice (the term in this context including management, policy-making, regulation and training as well as direct practice). The modules were designed to equip candidates to carry out service user roles in activities such as research priority setting; as membership of research committees and grant awarding panels; and in the implementation of research findings. These modules, respectively, achieve the Postgraduate Certificate, Postgraduate Diploma and MSc in Development and Co-Production of Social Care Research. This paper plots the journey; describes the content; draws on the direct experiences of participants; provides examples of outcomes of study; and indicates ideas for further development.

\section{Background}

Internationally there is increasing commitment to the involvement of service users and carer engagement in research (Callard \& Rose, 2012). There are some examples of coproduction initiatives in health care (Heaton et al., 2016; Parkes et al., 2014) but fewer in social care (Stevenson \& Taylor, 2019). A study by Gutman \& Ramon (2016) suggested that participatory models fitted well with "the inclusion of older people who use health and social care services as co- authors" (p.881). Social work examples of coproduction generally relate more to education than to research (Levy, 2016).

In recent years research funders have responded proactively to the ethical, moral, policy and legislative requirements requesting evidence of the active engagement of service users and carers in the research process. The approach in the United Kingdom reflects initiatives such as the Health and Care Social Care Act (2012). In Northern Ireland the newer concept of personal and public involvement (PPI) including in research is now a legislative requirement for statutory health and social care organizations as laid down in the Health and Social Services (Reform) Northern Ireland Act (2009). To give effect to the legislative mandate, the Social Work Research and Continuous Improvement Strategy (2015) has prioritized the need for greater attention to the provision of training for service users and carers.

INVOLVE is part of the National Institute for Health Research (NIHR) for the UK, and is widely recognized as a leading voice promoting public participation in all stages of the research process in health and social care. This more dynamic and inclusive approach has been widely influenced by the social model of disability since the early $1980 \mathrm{~s}$.

Cooperation, participation, engagement and inclusion have long been the hallmarks of the social work profession, encouraging equality of opportunity and a respect for service user and carer involvement. There is a strong ethical and social justice argument for the promotion of service user and carer involvement in social work research which can also be a distinguishing feature from other forms of research (Dominelli, 2005). This more inclusive research also has the potential to be rewarding and resonates with the value base of the social work profession (Biskin et al., 2013). Social work researchers are also bound by a professional commitment to abide by the values of the codes of practice of the social work profession (Butler, 2002).

User involvement in research activity, as in service design, can be conceptualised as a continuum. The most commonly employed framework being that of "consultation", 
"collaboration" and "control" (Hanley et al., 2003). However, the differences between these levels are not very distinct with collaboration subsuming all activity between consultation and control. At one end of the continuum is the type of "involvement" which is often perceived as tokenism. In this approach service users or carers are invited to respond or comment on the quality of a service or a policy initiative based on a predetermined set of questions often devised by an academic researcher. Inviting service users and carers to respond to questionnaires or be involved in focus groups are activities which typify such passive involvement. Service user and carer involvement in research can mean much more than this (Smith et al., 2008; Wallcraft et al., 2009). In particular, in relation to research one can identify specific contributions of service users to topic selection, research design, data gathering, data analysis and dissemination.

A fourth-level contribution between consultation and collaboration is starting to be articulated within the vocabulary of user involvement where service users make a substantial impact, through for example, acting as interviewers and researchers but have no access to decision-making processes. The other end of the continuum is characterised by a very different ideology more akin to collaboration where service users and carers share the research platform alongside academic and other experienced researchers more typically reflective of the principle of parity including decision making. Newer terms such as "codesign" and "coproduction" in this context are often used to describe such an approach. Debate still abounds in the literature about the accuracy of further developing the hierarchy typology of involvement derived from Arnstein's (1969) ladder of participation with some arguing that different approaches and strategies are in fact appropriate for different projects (Hanley et al., 2003). Other studies (e.g. Smith et al., 2008) suggest that there are different purposes and domains for service user and carer involvement either as part of a researcher led or user led research or as part of a partnership approach.

Notwithstanding this ongoing debate, there are clear epistemological and moral arguments for service user and carer involvement in research (Cossar \& Neil, 2015) alongside more experienced researchers where their knowledge and skill from experience is valued thereby offering an alternative discourse of equality, parity, reciprocity and the promotion of a shared agenda. The role of education and training has a key role to play in this.

\section{Method}

\section{Context of the Post-qualifying Social Work Programme}

Through partnership arrangements between Ulster University and local employers, one of the post-qualifying, postgraduate programmes available to social workers in Northern Ireland is the Research Methods Programme (Taylor et al., 2010). The minimum requirement for attendance is five years post-qualifying experience; participants are typically ten-years qualified. The aim of the present initiative was to create a similar learning experience for service users and carers. The Research Methods Programme has had various structures since it began in 1992. For the present purpose, we will describe only the current arrangements.

The 'Research Methods Programme' comprises three part-time modules each lasting one academic year. For social workers, their three modules lead to the MSc in Professional Development in Social Work. For service users and carers, their three modules lead to the MSc in Development and Co-Production in Social Care Research. The content of the parallel modules is essentially the same, although distinct module codes are required for each group as the modules for social workers must be accredited by the professional regulatory body, the Northern Ireland Social Care Council (NISCC). Classroom teaching is undertaken entirely with social workers and service users together, and the academic entry requirements are the same. The three modules undertaken in sequence focus on, respectively:

$>$ Stage 1: identifying, appraising and synthesising research;

$>$ Stage 2: undertaking a research or service evaluation project; and

$>$ Stage 3: transferring knowledge into practice. 
The Stage One module for service users and carers is titled: Using Evidence to Inform Professionals and Organisations. As well as general teaching (Taylor etal., 2015), this uses concepts in three skill areas:

- searching bibliographic databases to identify relevant research (Bates et al., 2017; Best, Taylor et al., 2014; Campbell et al., 2018; McElhinney et al., 2016; McFadden et al., 2012; McGinn, Taylor, McColgan, \& McQuilkin, 2016; Stevenson et al., 2016; Taylor et al., 2003; Taylor, Wylie, et al., 2007);

- appraising research quality (Taylor et al., Dempster et al., 2007); and

- undertaking a narrative synthesis of key findings (Agnew et al., 2010; Best, Manktelow et al., 2014; Fleming \& Taylor, 2010; Hagan et al., 2014; Killick et al., 2015; McFadden et al., 2015; McGinn, Taylor, McColgan, \& Lagdon, 2016).

Stage One is assessed through a written report and an oral presentation, following 'permission to proceed' based on a written proposal.

The Stage Two module requires candidates to undertake a research or evaluation project in a social work service delivery organization (Campbell et al., 2016; Hamilton et al., 2015; Kirk et al., 2019), building on the literature review in Stage One. For social work students, the project is undertaken within their employing body and the project must be approved by their line management. A parallel arrangement has been developed, through the employer partnership arrangements, such that the service users undertake a project of value to a social work service delivery organisation. Student projects are generally limited to qualitative designs (to understand perspectives in people's own words, and to create theory) or survey designs (to measure prevalence and correlation) (Taylor \& Moorhead, 2020). Experimental designs of effectiveness (Taylor, 2012b) are generally too complex and time-consuming for this MSc Course, although some students carry out simple pre-post testing using t-tests to measure change. Stage Two is assessed through a written report and an oral presentation, following 'permission to proceed' based on a written Proposal.

The Stage Three module focuses on supporting students to undertake activities to transfer knowledge into practice. The focus is on three elements:

- adapting your material to a suitably challenging audience (a conference presentation);

- writing the 'version of record' in summary form in a style suited to an international audience (a journal article); and

- providing evidence of competence in some knowledge transfer task(s) involving enabling others (interpersonal skills), such as being on a research committee or mentoring or teaching about research methods or literature reviewing.

Stage Three is assessed on the basis of the range of materials submitted, including the submitted journal article; the abstract and PowerPoint of the conference presentation; and testimonials and other evidence of enabling others in knowledge transfer.

The above structure applies to service users as well as to social workers, each carrying out the required tasks appropriate to their role in relation to social care research. The only formal difference in the assessment is that the social workers are assessed against the Professional-in-Practice post-qualifying Requirements of the professional regulatory body, NISCC, as well as against the academic learning outcomes, whereas the service users and carers are assessed against the academic learning outcomes only. As the academic learning outcomes are written to dovetail with the professional learning requirements (through a joint academic-professional body validation process every five years), there is minimal difference in practice for this Research Methods Programme.

Support for both social workers and those who are service users and carers is provided by a University tutor and by a 'Practice Assessor' appointed by a social work service delivery organisation. The origin of the term 'Practice Assessor' is lost in the unwritten 25-year history of the Research Methods Programme but refers to the fact that the person has a role in assessment as well as in mentoring and supporting through liaison within the organisation (such as with senior managers and the research governance department). For the small number of service users and carers to date, the main statutory social work organizations (the Health and Social Care Trusts) have agreed to provide Practice Assessors. 
An additional feature of the Programme is that service users are involved in contributing to marking the oral presentations, to ensure that candidates have an awareness of a service perspective, not only a professional one. The oral presentations assessed in Stage One and Stage Two takes place at a regional meeting to which key interested parties from the contributing employer organizations are invited (about 40 people in total). The assessment of the oral presentations for all candidates includes a service user (not a participant on the programme) contributing comments on each presentation. The University tutor and employer mentor retain any legal responsibility for the assessment, and this responsibility cannot be placed on a service user. However the markers must indicate how they have taken into account the comments of the service user marker when they write their assessment comments.

\section{Policy Context for Developing Service User and Carer Skills}

In 2015 with the launch of the Social Work Research and Continuous Improvement Strategy for Northern Ireland 2015-2020 (HSCB 2015), foundations were laid for building capacity, capability and confidence of social work staff to engage in evidence and research through appropriate supports and training. Consideration of the needs of service users and carers for training in research methods was also recognised as an integral part of this strategy.

The moral and ethical commitment for service user and carer engagement in research also brought recognition of the practical need to build a pool of appropriately trained service users and carers. The intention was to promote a research-minded organizational social work culture as well as improving professional knowledge and skills. In embracing the ethos of social work, emphasis was placed on parity of participation. Whilst acknowledging the valid role of experiential knowledge often referred to as 'experts by experience', the belief was that the coproduction would be better realized through having service users trained in rigorous research methods. The idea for opening the application process for the Research Methods Programme to service users and carers came from Research and Governance in the Health and Social Care Board. The Programme Director of the Research Programme at Ulster University took responsibility for module design and accreditation.

Once launched, the new module: Using Evidence to Inform Professionals and Organizations required candidates undertake a review of the empirical evidence on a relevant topic, learn to use web based sources of evidence, appraise and synthesise evidence into recommendations to inform social work practice. See Table 2.

Some funding for the involvement of service users and carers was secured from the local Health and Social Care Board, although recruitment was open to other service users and carers who met the normal academic criteria for postgraduate study, as for the social workers on the parallel modules. Given the many different purposes and domains for service user and carer involvement in research activity, it was important from the outset as part of the developmental process that Management Board agreed expected outcomes. It was agreed that the modules be designed to equip candidates to carry out service user roles in developing social care research, user involvement in priority setting and commissioning structures, as membership of research committees and grant awarding panels and in the dissemination and implementation of research findings.

The professional regulatory body, NISCC, gave encouragement to the initiative and was keenly supportive even though not directly involved in accrediting the service user modules.

\section{Evaluating the Learning and Impact}

The commitment to learning and development in research and evidence through the provision of this research methods programme was matched by a commitment to measure any change in participants' critical thinking, skills and knowledge. Adopting level 2 of Kirkpatrick's (1994) model of evaluation of training pre and post-tests of skills, knowledge (questionnaire) and a self-efficacy (confidence) scale were devised, piloted and administered before and after the ten month training course. Data was collected on 36 participants over the three year period 2016-2019. Responses from both social workers and service users and carers were collated and anonymised. It was impossible to disaggregate the data. Given the small numbers involved 
on the course these were self-assessment questionnaires and a non-validated scale devised in accordance with the course learning objectives and module content. The test of knowledge included 15 questions covering research methodology, searching databases, synthesis and ethics. Marking constituted positive marking utilising one mark per correct answer with negative scoring avoided due to complications associated with multiple choice questions. The selfefficacy (confidence) scale included 24 items self-rated by candidates on a scale between 0 100. It covered their confidence in understanding the local context, data base searching, appraising, dissemination and encouraging others to adopt evidence. The Statistical Package for Social Sciences (SPSS) was used to conduct paired t-tests.

At the end of each teaching block tutors collated qualitative comments orally and through a customised feedback sheet. These related to structure, form and content. As this was a new initiative it was important to gain this type of feedback from participants. In addition, a straightforward questionnaire for similar data was devised and administered by the tutors to candidates at the end of each year. This allowed for some general reflections on participants'experiences on being back in a classroom setting; whether this changed during the training; and their experience of challenges and achievements. This provided both groups of participants opportunity for comment on the strategic approach taken to involve service users and carers as peer learners with social workers. A thematic analysis of this feedback was undertaken.

\section{Results}

\section{Initial Experience of Delivery}

In year one, one service user embarked on the first year module, sitting alongside 10 12 experienced social workers. The classroom experience and the feedback from social work practitioners indicated a positive impact on social workers' attitudes on service user involvement and a value for the individual service user's personal development, confidence motivation, skills and general impact on her life. The decision to progress and further develop the pilot was a natural one to take. Some of the comments for example that helped influence this decision included: "it brought an invaluable insight and enhanced the importance of working in partnership with those with expert opinion; reinforced the many shared agendas; increased knowledge and understanding of service users views and the made an invaluable contribution as we progress on a mutually beneficial learning journey together". The following year, three service users commenced the first year module.

From the outset compatibility with social work professionals and parity of participation in the learning and development opportunity was a key principle. Social work participants have a mentor ('Practice Assessor') nominated by their employer, who ensures that the projects are relevant to current service delivery issues. This person facilitates communication in the organisation for the candidate (e.g. with senior management, research governance arrangements, data protection officer) as well as providing a 'second supervisor' role alongside the University tutor. The support for service users, the employers were asked to provide (on an informal, rotating basis) a similar mentor.

At the outset we anticipated that service users and carers would generally select projects related to coproduction topics. However this turned out to be a minority, and most have selected topics in which they are particularly interested. This is essentially the same as for the social workers, although social workers have to have support of their line management for topics. Conversely, of course, some social workers have undertaken coproduction projects. From the perspective of those teaching on the course, a key issue is that the service users and carers have generally chosen topics 'close to their hearts', such as an aspect of their experience as an adoptive parent, engagement with professionals when your child is dying from cancer, experience as a parent within child protection procedures, or receipt of mental health services. This has meant that greater emotional sensitivity has been required in challenging students along their journey. 
The total involvement of service users and carers is currently eight over three entry cohorts. This paper reflects the period 2016-2019. Each of these individuals is at a different stage in their academic journey. Each has addressed a range of subject areas relevant to social care research. Two have completed a systematic narrative review of evidence on a selected topic; four have subsequently gone on to conduct their own small service user and carer-led projects; one person has completed the knowledge transfer third year of the MSc programme.

\begin{tabular}{|c|c|c|c|c|}
\hline Participant & Topic area of interest & $\begin{array}{l}\text { Year } 1 \\
\text { Evidence } \\
\text { Review: } \\
\text { Postgraduate } \\
\text { Certificate }\end{array}$ & $\begin{array}{l}\text { Year } 2 \\
\text { Research or } \\
\text { Evaluation } \\
\text { Project: } \\
\text { Postgraduate } \\
\text { Diploma }\end{array}$ & $\begin{array}{l}\text { Year } 3 \\
\text { Knowledge } \\
\text { Transfer } \\
\text { Activities: } \\
\text { MSc }\end{array}$ \\
\hline 1 & $\begin{array}{l}\text { Co-training for co- } \\
\text { production in health and } \\
\text { social care }\end{array}$ & $\checkmark$ & $\checkmark$ & $\checkmark$ \\
\hline 2 & Adoption breakdown & $\checkmark$ & $\checkmark$ & $\begin{array}{l}\text { Currently } \\
\text { participating }\end{array}$ \\
\hline 3 & $\begin{array}{l}\text { Adoption and school } \\
\text { experiences }\end{array}$ & $\checkmark$ & $\checkmark$ & $\begin{array}{l}\text { Currently } \\
\text { participating }\end{array}$ \\
\hline 4 & $\begin{array}{l}\text { Parental alienation in } \\
\text { separation and divorce }\end{array}$ & $\checkmark$ & $\begin{array}{l}\text { Currently } \\
\text { participating }\end{array}$ & \\
\hline 5 & $\begin{array}{l}\text { Co-production in mental } \\
\text { health recovery colleges }\end{array}$ & $\checkmark$ & $\begin{array}{l}\text { Currently } \\
\text { participating }\end{array}$ & \\
\hline 6 & $\begin{array}{l}\text { Physical activity for } \\
\text { mental health }\end{array}$ & $\begin{array}{l}\text { Currently } \\
\text { participating }\end{array}$ & & \\
\hline 7 & $\begin{array}{l}\text { Early onset dementia and } \\
\text { family carers }\end{array}$ & $\begin{array}{l}\text { Currently } \\
\text { participating }\end{array}$ & & \\
\hline 8 & $\begin{array}{l}\text { Parental involvement in a } \\
\text { child's healthcare } \\
\text { decisions }\end{array}$ & $\begin{array}{l}\text { Currently } \\
\text { participating }\end{array}$ & & \\
\hline
\end{tabular}

Figure 1: Progress of Service User and Carer Participants on the Research Methods Programme at October 2019

Table 1 and Table 2 represent descriptive statistics based on 36 students who participated on the EIPO Module 2016-2019 showing pre and post design mean scores for knowledge and self-efficacy (confidence).

Table 1 Pre and Post Design (Knowledge and Self-efficacy) Paired Sample Statistics

\begin{tabular}{|c|c|c|c|c|c|c|}
\hline & & & Mean & $\mathrm{N}$ & Std. Deviation & $\begin{array}{l}\text { Std. } \\
\text { Mean }\end{array}$ \\
\hline \multirow[t]{2}{*}{$\overline{\text { Pair } 1}$} & $\begin{array}{l}\text { Pre-design Score } \\
\text { (Knowledge) }\end{array}$ & & 7.11 & 36 & 1.753 & .292 \\
\hline & $\begin{array}{l}\text { Post-design } \\
\text { (Knowledge) }\end{array}$ & Scort & 11.08 & 36 & 1.763 & .294 \\
\hline \multirow[t]{2}{*}{ Pair 2} & $\begin{array}{l}\text { Pre-design Score } \\
\text { Efficacy) }\end{array}$ & (Sel & 998.61 & 36 & 256.216 & 42.703 \\
\hline & $\begin{array}{l}\text { Post-design Score } \\
\text { Efficacy) }\end{array}$ & (Sel & $\begin{array}{l}1477.4 \\
2\end{array}$ & 36 & 167.269 & 27.878 \\
\hline
\end{tabular}

There was an increase in post design score for knowledge $M=(11.08)$ compared with pre design score (knowledge) $M=7.11$. There was also an increase for post design score for (self-efficacy) $M=(1477.42)$ compared with pre design score self-efficacy $M=998.61$ ). 
Table 2 Pre and Post Design (Knowledge and Self-efficacy) Paired Differences

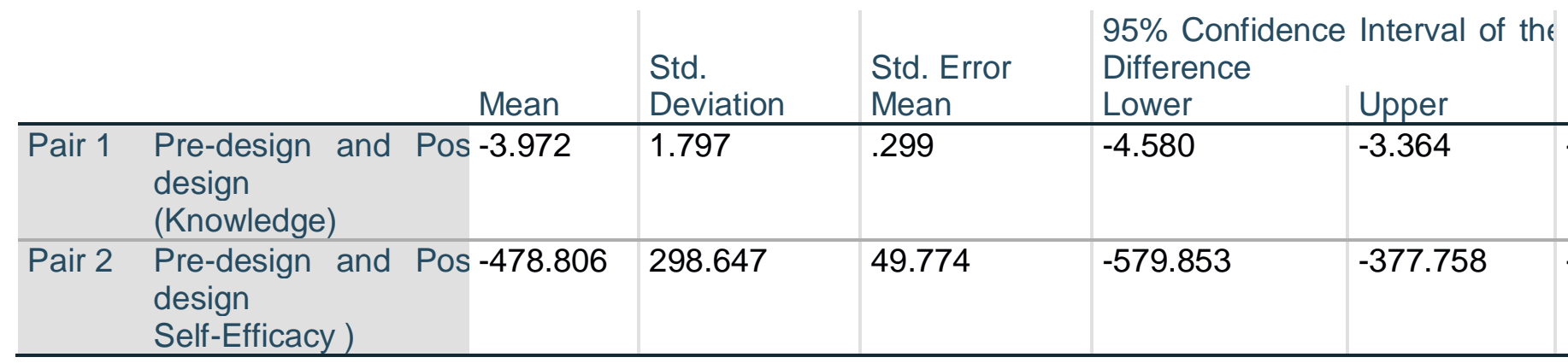

Figures presented in Table 2 in this Paired Samples Test Table indicate that there was a significant difference in the scores for pre and post designs Knowledge $(M=-3.97, S D=$ 1.79) conditions $t(35)=-13.26, p<.001$ and for pre and post designs $M=-478.80, S D=298.64$ conditions; $\mathrm{t}(35)=-9.62, \mathrm{p}<.001$. For reasons already reported earlier in this paper (small numbers, non-validated tool and self-assessments scoring, plus the fact that no other factors were controlled) the results need to be treated with caution but do offer some optimism. There is a high probability that the results reported were related to the training input.

All members of the cohort were offered an opportunity after each teaching block to evaluate the programme's strengths and weaknesses in terms of structure, format, and content. The evaluations indicated that the planning; design and delivery structure of the programme was above expectations with individual units of learning positively evaluated. Any suggestions for improvement were considered and where feasible were addressed on an ongoing basis.

End of year evaluations and reflections were collected and thematically analysed to provide a more comprehensive overview of candidates' experiences in a number of areas; experience of the classroom setting; challenges and achievements and perceptions of the strategic approach adopted to train service users and carers and social work professionals together. This was an issue of importance for the Programme's Management Board. As responses were anonymised and disaggregated views from the two groups was not possible, but overall a promising picture emerged.

Question to social workers: The involvement of service users as peer learners with social workers in the review module was devised as an approach to:

- Ensuring "quality of participation" ensuring a better sense of integration

- Prepare both groups together for a role in social work research

From your experience of the review module do you think that the experience provides an environment where service users and carers and social work practitioners better understand each other?

1. This process is valuable as it allowed me to get the service users perspective first hand.

2. Limited opportunity for formal intervention or exploring of this but plenty of informed contact.

3. Absolutely \& Totally

4. Yes, absolutely having the opportunity to learn together provides a unique perspective \& further insight.

5. Yes this was a fantastic opportunity to get both perspectives. 
6. Yes and it is lovely to see a genuine sense of partnership between both groups. In fact it doesn't feel like two distinct groups. This is what co production should be.

Question: What did your experience of this approach bring to you personally?

1. Gained more insight into the world of social workers and gained confidence to have my voice heard as a service user.

2. Knowledge of how to thoroughly extract information from research and combine findings.

3. Maybe a bit more empathy for social workers and the frustration of their role.

4. Highlights the clinical importance of working in partnership - listening to the other expert opinions.

5. Value of the service user perspective what is important \& indeed realistic.

6. Look at learning curve more broadly, looking at themes \& issues particularly to service users.

Question: In relation to these two objectives in what ways do you think the experience might influence your own role?

1. Honing further my knowledge base - influencing practice in assessment and support to service group.

2. As a service user has given me more confidence about understanding research and about getting involved in co-production etc.

3. More informed become a greater advocate for PPI highlight to peers/colleagues. Direct career path \& inform.

4. It would be useful in the future to possibly encourage service user to apply for this course if they are interested.

5. I think it has helped me to consider different perspectives -EIPO is a great idea but limited opportunities in my field.

6. I will be able to understand and recognise the social workers can contribute to an enormous change.

Question: Any other comments welcome

1. Excellent course.

2. Really enjoyed the course, though at times questioned my decision to do it!

3. Many positive benefits on personal as well as practice level.

4. I really got a lot out of course and actually missed being in the class at times.

5. In an ideal world it would be great to have more than two/three service user/carers places.

6. By availing of their different approaches to situations would enable me to also take an independent view and review my role with more respect.

Question: Add three words that come to mind to describe your experience of participation on this post qualifying training module.

1. Enlightening, Stressful \& Consuming

2. Practical, Challenging \& Beneficial

3. Rewarding, Positive \& Enjoyable 
4. Enthralling, Stimulating \& Demanding

5. Educational, Terrifying \& Worthwhile

6. Confidence building, Inspiring \& Developing

\section{Figure 2: Candidates' reflections on their learning journey}

Overall there were similarities in service user's and carers feelings of trepidation and anxiety at being back in a classroom setting, especially if this was after a spell away from study. Words like "anxious, daunted and overwhelmed" and fears about not being equipped with the language common at post-graduate level and in particular "a whole new language of research and evidence" were articulated. To balance these comments, feedback indicated that there was a genuine sense of excitement at starting a "new venture", "interest in meeting others who are also interested in research". For some the "supportive learning opportunity" was appreciated. Challenges of "time management and work life balance" dominated the feedback as did the fact that the course was academically challenging.

Analysing the comments about the strategic decision to involve service users and carers in the learning environment, responses were overwhelmingly reported as "absolutely the right decision". In practice the experience of learning together "brought a new and unique experience", and in the classroom there was "not a sense of two distinct groups" but rather one of "equality". The training also offered "an insight into each other's worlds" and particularly from service users the opportunity to have "my experience and intellect valued alongside social work practitioners".

In terms of longer-term impact, comments from social workers indicated a greater appetite for revisiting service user involvement and genuine participation in "my daily practice and service forums". Equally, however, a service user indicated a greater recognition and appreciation of the way that social workers genuinely wish to contribute to challenging change processes in service development.

The experiences of three of the authors of this paper offer the reader an opportunity to gain a greater appreciation of choice of study topic, and personal reflections on experience of participation. Three of the co-authors have already articulated their motivation for participating and their experiences of doing so in an additional promotional video which is available by contacting the main author of this paper. Sharing their personal stories is intended to act as a motivating factor for others. A thematic approach has been adopted for the purposes of this paper, summarizing the key messages.

One author a Co-Production Advocate in the Regional Northern Ireland Cancer Research Consumer Forum (NICRCF) was motivated to participate because of her service user experiential knowledge of working with academia and clinicians in cancer research. The course was perceived to be a far reaching and unique opportunity to gauge the extent of coproduction within social work, yet "I initially struggled with its relevance". The training supported the conduct of a systematic narrative review which revealed that, despite policy initiatives, a dearth of robust empirical evidence existed on coproduction in social work. Another author, an adoptive parent employed in the voluntary sector in a peer support and advocacy role, also welcomed the opportunity to participate in the Research Methods Programme. The motivating factor was the chance to represent more effectively the voice of local adoptive families to the service providers tasked with supporting them. "I could see the need to present robust, credible evidence in this area and while aware of some research into adoption disruption carried out in England and Wales, I had scanty knowledge of world-wide research and was aware of none on the topic in Northern Ireland". Likewise another author, an adoptive parent, trainer with Adoption UK and a qualified teacher, had become increasingly aware that adopted young people can find the school environment a very challenging place due to their adverse early life experiences. The training offered an opportunity to explore the issues in a more systematic way.

Support was particularly important "during my three-years as a service user student on the Research Methods Programme, the funding organisation and academic staff have provided unending support". This is provided through ongoing classroom support, the support of a tutor, 
a practice assessor, meetings, telephone calls, emails and through advice and resources provided through the University digital learning environment. Such support is available for all participants but was particularly welcome by service users because of initial feelings of trepidation. "It was a real baptism of fire. I had been out of the working world for almost nine years to be at home with my children and I now found myself in a class of professionals studying at Masters Level". "The Research Methods Programme has enabled me to develop my knowledge and skills as a researcher and has given me the opportunity, with the guidance and support of academic staff, mentoring tutors and fellow participants on the course to undertake research in this area".

Another key message emerging was the importance of the principle of equality. "The genuine belief in equality of participation has been invaluable. I have thoroughly enjoyed the opportunity to learn 'experientially' and to be an 'active team member' in developing social work and social care research". "It has been an enlightening experience to study alongside social workers and other service users each bringing their own experiences and passionate interest in their field of study. Early reticence to engage openly in the group was gradually overcome with the realisation that we were an even field of players facing the same challenges of getting to grips with the world of research".

The building of relationships within a training setting is often perceived as an invaluable aspect of learning and development and no less so for the programme. "As one year turned into two and then three, the bonds amongst the members of my class has deepened and grown". "There has undoubtedly been a depth of learning on the part of the social workers and service users and carers which has only come about because we are sharing the same space". "As relationships strengthened within the group, there were opportunities to reflect on the different but equally valuable perspectives brought by service users and practitioners to the benefit, I believe, of both." "Mutual respect for the role we each play has grown. I am planning to complete year three and am excited about the ways in which I can share the findings of my research and influence policy to bring an improvement to the experience of adopted young people in school".

Confidence can be enhanced in areas of skill and knowledge also evidenced by the statistical evidence reported earlier in this paper. The Research Methods Programme has been influential in providing training, support and greater confidence to contribute to other roles in research. "Participation in training has supported my role as a patient advocate on the Research Governance committee of my local Health and Social Care Trust. My role is to draw on my own skills and experiences to contribute to discussions which may help improve." "Receiving the training afforded me greater confidence to search for robust evidence on adoption rather than anecdotal evidence". "Having undertaken year one and year two I am confident that year three of the course will help me present the key findings of the project to relevant audiences to make an impact on service for adopted children in school."

A number of anticipated spin-offs have already happened or will in the future. "As a direct result of participation in the programme I had the opportunity to present the findings of my literature review to adoption practitioners at two seminars organised by the Health and Social Care Board. I have been invited to participate on an equal status as a member on a Project Board of a major evaluation exercise in relation to fostering services reflecting both my research knowledge and experience as a foster carer as well as an adoptive parent". For another author "since commencing the course, I have had important openings to highlight my area of study. I presented a poster at the Regional Northern Ireland Social Work Research Conference 2019, presented my literature review as part of a HSC Social Workers and Community Development Programme 2019 with an invitation to return with an update on my research findings for 2020. More recently I was invited to provide a keynote address at the regional research conference in Northern Ireland. A real highlight for me was being able to copresent alongside two of the young people I had interviewed for my research". For another author "since being involved in the course I have acquired greater confidence to contribute to my work in the Northern Ireland Cancer Research Consumer Forum (NICRCF), Cancer Centre, Belfast. This involves working collaboratively with clinical researchers from Queen's University Belfast. As a member of the forum I, along with other members, have oversight of research 
conducted and influence a range of research projects including new approaches in the treatment."

\section{Discussion}

This post-graduate research methods and evidence-into-practice learning experience introduced by Ulster University and employer partners was based on the principle of "equality of participation' in coproduction of social care research. It is still in its infancy and is relatively small scale. Pre and post testing was introduced to evidence to what extent the training intervention was making any difference in terms of knowledge skills and confidence or selfefficacy. To-date the tools used are non-validated so results need to be treated with caution.

The reflections by participants on the programme indicated that social work practitioners valued engaging with service users' experiences during their studies. Equally, service users and carers indicated that participation enabled them to appreciate much better the complexity of social work practice, and the context in which evidence has to be used (Taylor et al., 2015). Such involvement afforded by the post qualifying opportunity can enable transformative learning and true partnership working (Rush, 2008).

Training service users and carers alongside social work practitioners resonates with the value base of the social work profession, reflects inclusivity, and, as demonstrated by participants, has the potential to be rewarding and fulfilling. The initiative was supported by the Strategic Priority 7 of the Social Work Research and Continuous Improvement Strategy 20152020 (HSCB 2015) for Northern Ireland, which highlights the need for "mechanisms, including the provision of training, to be put in place for the engagement and involvement of service users and carers to enhance Personal and Public Involvement."

An observation over the three years of the Programme has been the increasing number of social workers on the Programme whose reviews and projects include co-design and coproduction as a way of working. The involvement of service users in the assessment of oral presentations has helped to create a coproduction culture. Relationships built up through participation on the Programme has facilitated more natural alignments for coproduction working in the delivery of outcomes and in joint publications in peer reviewed journals.

The projects undertaken by service users, as much as those by social workers, have the potential to contribute to developing services at 'grass-roots' level (Hickey et al., 2018; Loughran \& McCann, 2015). Undoubtedly some credit for this is due to the close involvement of employers, and the appointment of employer mentors who ensure relevance of projects to the candidate's work role from the outset. Larger research projects, such as on PhDs, are more suitable for 'blue-skies thinking' and for regional developments such as the design of assessment tools [Fengler \& Taylor, 2019; Taylor, 2012a]. The projects produced by participants on this Programme, however, are very well suited to creating change built on robust knowledge within a smaller domain, appropriate to the student's role.

The development of coproduction of social work research links to the growing 'governance' agenda (Taylor \& Campbell, 2011) with its twin concerns of developing quality and managing risk. Closer working with service users in social care research can bring risks, but can also enhance quality of the research and hence of services.

\section{Conclusion}

This paper outlined and discussed the design, delivery and outcomes of a postgraduate course in: Development and Co-Production of Social Care Research. The course is innovative in providing training for service users and carers to develop knowledge and skills relevant to undertaking roles in coproduction of social care research. The initiative is also innovative in that the Programme is conducted jointly with experienced social workers undertaking the same learning journey in literature reviewing; research or evaluation projects; and transferring knowledge to practice. Formal and informal feedback on the learning experience is overwhelmingly positive. The ultimate aim of equipping service users and carers to participate effectively in social care research activities is in the short term beginning to show 
evidence of success. For the potential of the post qualifying training to be realised in the longer term, it is important that those provided with the opportunity to participate have opportunity and continue to utilise their skills learned in a context of coproduction of research. These types of initiatives indicate the importance of service users and carers having more proactive and meaningful roles in research-related activity.

Key findings from this study are that it is viable to have a structured programme for systematic development of the knowledge and skills of service users and carers designed to equip them to carry out their roles within social work research, such as on research advisory groups and grant awarding panels. This applies whether or not their topic was focused on coproduction, and in practice few chose to focus on this as a topic. Nonetheless, the knowledge and skills relating to research and to evidence-into-practice as well as the learning process alongside experienced social workers promises prepare them well to play their part in coproduction of social work research.

\section{Acknowledgements}

We would like to thank the tutors, practice assessors and participants on the Research Methods Programme who have made the learning journey so enjoyable as well as valuable.

\section{References}

Agnew, A., Manktelow, R., Taylor, B. J., \& Jones, L. (2010). Bereavement needs assessment in specialist palliative care settings: a review of the literature. Palliative Medicine, 24(1), 46-59. https://doi.10.1177/0269216309107013

Arnstein, S. R. (1969). A ladder of citizen participation. Journal of American Institute of Planners, 35(4), 216-224. http://doi.10.1080/01944366908977225

Bates, J., Best, P., McQuilkin, J., \& Taylor, B. J. (2017). Will web search engines replace bibliographic databases in the systematic identification of research? Journal of Academic Librarianship, 43(1), 8-17. http://dx.doi.org/10.1016/j.acalib.2016.11.003

Best, P., Manktelow, R. \& Taylor, B. J. (2014). Online communication, social networking and adolescent wellbeing: a systematic narrative review. Children and Youth Services Review, 41, 27-36. https://org/10.1016/j.childyouth.2014.03.001

Best, P., Taylor, B. J., Manktelow, R., \& McQuilkin, J. (2014). Systematically retrieving research in the digital age: case study on the topic of social networking sites and young people's mental health. Journal of Information Science, 40(3), 346-356. https://doi.10.1177/0165551514521936

Biskin, S., Barcroft, V., Livingston, W., \& Snape, S. (2013). Reflections on student, service user and carer involvement in social work research. Social Work Education, 32(3), 301-316. https://doi.10.1080/02615479.2012.656267

Butler, I. (2002). A code of ethics for social work and social care research. British Journal of Social Work, 32(2), 239-248. https://doi.org/10.1093/bjsw/32.2.239

Campbell, A., Taylor, B. J., Bates, J., \& O'Connor-Bones, U. (2018). Developing and applying a protocol for a systematic review in the social sciences. New Review of Academic Librarianship, 24(1), 1-22. https://doi.10.1080/13614533.2017.1281827

Campbell, A., Taylor, B. J., \& McGlade, A. (2016). Research design in social work: Qualitative and quantitative methods. Sage.

Callard, F. \& Rose, D. (2012). The mental health strategy for Europe: why service user leadership in research is indispensable. Journal of Mental Health, 921(3), 219-226. https://doi.10.3109/09638237.2011.651661

Cossar, J. \& Neil, E. (2015). Service user involvement in social work research: learning from an adoption research project. British Journal of Social Work, 45 (1), 225-240. https://doi.org/10.1093/bjsw/bct108

Dominelli, L. (2005). Social Work research: Contested knowledge for practice. InR. L. Adams, L. Domeinelli, \& M. Payne (Eds.), Social work futures: Crossing boundaries, transforming practice (pp. 241-257). Palgrave MacMillan. 
Fengler, J. \& Taylor, B. J. (2019). Effective assessment: a key knowledge and skill for a sustainable profession. Social Work Education: The International Journal, 38(3), 392405. https://doi.10.1080/02615479.2018.1538333

Fleming, G. \& Taylor, B. J. (2010). An evaluation of day support: a community rehabilitation service? International Journal of Disability, Community and Rehabilitation, 9(1). ISSN 1703-3381. http://www.ijdcr.ca/VOL09_01/articles/taylor.shtml

Gutman, C. \& Ramon, S. (2016). Lessons from a comparative study of user involvement. Social Work Education, 35(8), 878-891. https://doi.10.1080/02615479.2016.1221392

Hagan, R., Manktelow, R., Mallett, J., \& Taylor, B. J. (2014). Reducing loneliness amongst older people: systematic search and narrative review. Aging and Mental Health, 18(6), 683-693. https://doi:10.1080/13607863.2013.875122

Hamilton, D., Taylor, B.J., Killick, C., \& Bickerstaff, D. (2015). Suicidal ideation and behaviour among young people leaving care: case file survey. Child Care in Practice, 21(2), 160 176. https://doi:10.1080/13575279.2014.994475

Hanley, B., Bradburn, J., Barnes, M., Evans, C., Goodare, H., Kelson, M., Kent, A., Oliver, S., Thomas, S., \& Wallcraft, J. (2003). Involving the Public in NHS Health and Social Care Research Briefing Notes for Researchers ( $2^{\text {nd }}$ ed.). INVOLVE.

$\begin{array}{lllll}\text { Health and Social Care } & \text { Act } & \text { 2012, } & \text { c.7. }\end{array}$ http://www.legislation.gov.uk/ukpga/2012/7/contents/enacted

Heaton, J., Day, J., \& Britten, N. (2016). Collaborative research and the co-production of knowledge for practice: an illustrative case study. Implementation Science, 11: 20. https://doi.org/10.1186/s13012-016-0383-9

Hickey, G., Brearley, S., Coldham, T., Denegri, S., Green, G., Staniszewska, S., Tembo, D., Torok, K., \& Turner, K. (2018). Guidance on co-producing a research project. INVOLVE.

Killick, C., Taylor, B.J., Begley, E., Anand, J.C., \& O'Brien, M. (2015). Older people's conceptualization of abuse: a systematic narrative review. Journal of Elder Abuse and Neglect, 27(2), 100-120. https://doi:10.1080/08946566.2014.997374

Kirk, C.A., Killick, C., McAllister, A., \& Taylor, B. J. (2019). Social workers perceptions of restorative approaches with families in cases of elder abuse: a qualitative study. Journal of Adult Protection, 21(3), 190-200. https://doi.org/10.1108/JAP-12-2018-0029

Kirkpatrick, D. L. (1994). Evaluating training programs: The four levels. Berrett-Koehler.

Levy, S. (2016). Outcomes-focused user involvement in social work education: applying knowledge to practice. Social Work Education: The International Journal, 35(8), 866-877. https://doi.10.1080/02615479.2016.1240160

Loughran, H. \& McCann, M. E. (2015). Employing community participative research methods to advance service user collaboration in social work research. British Journal of Social Work, 45(2), 705-723. https://doi.org/10.1093/bjsw/bct133

McElhinney, H., Taylor, B. J., Sinclair, M., \& Holman, M. R. (2016). Sensitivity and specificity of electronic databases when searching for evidence on child protection issues related to pregnant women. Evidence Based Midwifery, 14(1), 29-34. ISSN:1479-4489

McFadden, P., Campbell, A., \& Taylor, B. J. (2015). Resilience and burnout in child protection social work: individual and organizational themes from a systematic literature review. British Journal of Social Work, 45(5), 1546-1563. https://doi:10.1093/bjsw/bct210

McFadden, P., Taylor, B.J., Campbell, A., \& McQuilkin, J. (2012). Systematically identifying relevant research: case study on child protection social workers' resilience. Research on Social Work Practice, 22(6), 626-636. https://doi:10.1177/1049731512453209

McGinn, A. H., Taylor, B. J., McColgan, M., \& Lagdon, S. (2016). Survivor perspectives on IPV perpetrator interventions: systematic narrative review. Trauma, Violence \& Abuse, 17(3), 239-255. https://doi:10.1177/1524838015584358

McGinn, A. H., Taylor, B. J., McColgan, M., \& McQuilkin, J. (2016). Social work literature searching: current issues with databases and online search engines. Research on Social Work Practice, 26(3), 266-277. https://doi:10.1177/1049731514549423

Moriarty, J., Rapaport, P., Manthorpe, J., Cornes, M., Martineau, S., Beresford, P., Branfield, F., Forrest, V., Butt, J., lliffe, S., Keady, J., \& Taylor, B. J. (2007). The participation of 
adult service users, including older people, in developing social care: SCIE guide 17. Social Care Institute for Excellence.

Parkes, J.H., Pyer, M., Wray, P., \& Taylor, J. (2014). Partners in projects: preparing for public involvement in health and social care research. Health Policy, 117: 399-408. https://doi.org/10.1016/j.healthpol.2014.04.014

Rush, B. (2008). Mental health service user involvement in nurse education: a catalyst for transformative learning. Journal of Mental Health, 17, 531-542. https:://doi.10.1080/09638230802053383

Stevenson, M. \& Taylor, B. J. (2019). Involving individuals with dementia as co-researchers in analysis of findings from a qualitative study. Dementia: The International Journal of Social Research and Practice, 18(2), 701-712. https://doi:10.1177/1471301217690904

Stevenson, M., Taylor, B. J., \& Knox, J. (2016). Risk in dementia care: searching for the

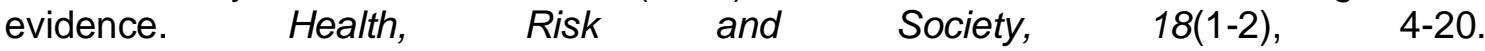
https://doi:10.1080/13698575.2015.1119256

Taylor, B. J. (2012a). Developing an integrated assessment tool for the health and social care of older people. British Journal of Social Work, 42(7), 1293-1314. https://doi:10.1093/bjsw/bcr133

Taylor, B. J. (2012b). Intervention research. In M. Gray, J. Midgley \& S. Webb (Eds.), The SAGE handbook of social work (pp. 424-439). Sage.

Taylor, B. J. \& Campbell, B. (2011). Quality, risk and governance: Social workers' perspectives. International Journal of Leadership in Public Services (NOW the International Journal of Public Leadership), 7(4), 256-272. https://doi:10.1108/17479881111194152

Taylor, B. J., Dempster, M., \& Donnelly, M. (2003). Hidden gems: systematically searching electronic databases for research publications for social work and social care. British Journal of Social Work, 33(4), 423-439. https://doi:10.1093/bjsw/33.4.423

Taylor, B.J., Dempster, M., \& Donnelly, M. (2007). Grading gems: appraising the quality of research for social work and social care. British Journal of Social Work, 37(2), 335-354. https://doi:10.1093/bjsw/bch361

Taylor, B. J., Killick, C., Bertotti, T., Enosh, G., Gautschi, J., Hietamäki, J., Sicora, A., \& Whittaker, A. (2017). European Social Work Research Association SIG to study decisions, assessment and risk. Journal of Evidence-Informed Social Work, 15(1), 8294. http://doi.10.1080/23761407.2017.1394244

Taylor, B. J., Killick, C., \& McGlade, A. (2015). Understanding and using research in social work. Sage.

Taylor, B. J. \& Moorhead, A. (2020). The social sciences. In Bahri P (Ed) Communicating about risks and safe use of medicines: Real life and applied research. (Chapter 8). Springer.

Taylor, B. J., Mullineux, J. C., \& Fleming, G. (2010). Partnership, service needs and assessing competence in post qualifying education and training. Social Work Education: The International Journal, 29(5), 475-489. https://doi.10.1080/02615470903159117

Taylor, B. J., Wylie, E., Dempster, M., \& Donnelly, M. (2007). Systematically retrieving research: a case study evaluating seven databases. Research on Social Work Practice, 17(6), 697-706. https://doi:10.1177/1049731507304402

Wallcraft, J., Schrank, B., \& Amering, M. (2009). Handbook of service user involvement in mental health research. Wiley-Blackwell. 